\title{
Efektivitas Pembentukan Belajar Mandiri Mahasiswa Baru S1 PGSD-UT Melalui Pelatihan Keterampilan Belajar Mandiri dan Tutorial dalam Peningkatan Kemampuan Penulisan Karya IImiah
}

\author{
Sulistiyono \\ Universitas Terbuka \\ email: sulistyono@ecampus.ut.ac.id \\ Barokah Widuroyekti \\ Universitas Terbuka \\ email: barokahw@ecampus.ut.ac.id
}

\begin{abstract}
Abstrak
Penelitian ini bertujuan untuk: (1) memperoleh gambaran tentang efektivitas pembentukan belajar mandiri melalui Pelatihan Keterampilan Belajar Mandiri dalam meningkatkan kemampuan Penulisan Karya IImiah di S1 PGSD-UT Pokjar Pamekasan 2017-2018.2; (2) memperoleh gambaran tentang efektivitas pembentukan belajar mandiri melalui perancangan tutorial dalam meningkatkan kemampuan Penulisan Karya IImiah di S1 PGSD-UT Pokjar Pamekasan 20172018.2. Berdasarkan tujuan tersebut, penelitian ini dilaksanakan menggunakan pendekatan penelitian deskriptif-kualitatif.

Proses analisis data dimulai dengan menelaah seluruh data, melakukan reduksi data, menyusunnya dalam satuan-satuan, dan menganalisnya dengan prosentase. Analisis data penelitian dilakukan dengan teknik analisis kuantitatif dan kualitatif. Data yang bersifat kuantitatif dianalisis dengan menggunakan penghitungan prosentase. Langkah ini merupakan langkah awal menuju keseluruhan proses analisis deskriptif kualitatif. Analisis data deskriptif kuantitatif berupa prosentase akan dijadikan dasar bagi penentuan efektivitas pada analisis deskriptif kualitatif dari variabel yang diteliti.

Aktivitas analisis meliputi: reduksi data, penyajian data, penyimpulan dan verifikasi. Kegiatan reduksi data meliputi klasifikasi data, pengkodean data sesuai dengan jenis data. Data disajikan dalam bentuk deskripsi.yang dilanjutkan dengan pemaknaan dan penyimpulan.

Melalui langkah-langkah penelitian tersebut, hasil temuan penelitian sebagai berikut. Pertama, temuan penelitian tentang pembentukan belajar mandiri melalui Pelatihan Kegiatan Belajar Mandiri dalam meningkatkan kemampuan Penulisan Karya IImiah di S1 PGSD-UT Pokjar Pamekasan 2017-2018.2 mencapai kualitas skor baik dan perolehan penguasaan yang sangat efektif. Kedua, temuan penelitian tentang efektivitas pembentukan belajar mandiri melalui perancangan tutorial dalam peningkatan kemampuan Penulisan Karya IImiah di S1 PGSD-UT Pokjar Pamekasan 2017-2018.2 mencapai skor baik dan perolehan penguasaan yang efektif. Ketiga, hasil karya ilmiah mahasiswa mencapai kualitas skor cukup dan perolehan penguasaan yang efektif.
\end{abstract}

Kata Kunci: Efektivitas, Belajar Mandiri, Tutorial, Pelatihan Keterampilan Belajar Mandiri 


\begin{abstract}
This study aims to: (1) obtain an overview of the effectiveness of the formation of independent learning through Independent Learning Activity Training in improving the ability of Scientific Writing at the PGSD-UT S1 Pokjar Pamekasan 2017-2018.2; (2) obtain an overview of the effectiveness of the formation of independent learning through designing tutorials in improving the ability of Scientific Writing at S1 PGSD-UT Pokjar Pamekasan 2017-2018.2. Based on these objectives, this research was carried out using a descriptive-qualitative research approach. The process of data analysis begins with examining all data, reducing data, arranging it in units, and analyzing it with percentages. The data analysis of the research was carried out by quantitative and qualitative analysis techniques. Quantitative data were analyzed using percentage calculations. This step is the first step towards the whole process of qualitative descriptive analysis. Quantitative descriptive data analysis in the form of a percentage will be the basis for determining the effectiveness of qualitative descriptive analysis of the variables studied. Analysis activities include: data reduction, data presentation, inference and verification. Data reduction activities include classification of data, coding of data according to the type of data. Data is presented in the form of a description. Followed by meaning and conclusion. Through the steps of the research, the research findings are as follows. First, research findings on the formation of independent learning through Independent Learning Activity Training in improving the ability of Scientific Writing at the PGSD-UT S1 Pokjar Pamekasan 2017-2018.2 achieve good quality scores and very effective mastery acquisition. Second, the research findings about the effectiveness of the formation of independent learning through designing tutorials in improving the ability of Scientific Writing at S1 PGSD-UT Pokjar Pamekasan 2017-2018.2 achieve good scores and effective acquisition of mastery. Third, students' scientific work achieves sufficient quality scores and effective mastery.
\end{abstract}

Keywords: Effectiveness, Independent Learning, Tutorials, Independent Learning Skills Training

\section{Pendahuluan}

Masalah krusial yang melatarbelakangi penelitian ini mencakup dua hal pokok. Pertama, mahasiswa baru UT pada umumnya dibentuk dalam sistem dan kultur pendidikan tatap muka sejak Taman KanakKanak sampai SLTA, bahkan di Perguruan Tinggi. Kedua, memasuki perkuliahan diUT, mereka dihadapkan pada sistem dan kultur pendidikan yang sangat independent dan berbeda, yang menuntut mahasiswa memiliki kemampuan membangun prakarsa belajar mandiri.

Dalam konteks belajar mandiri, kemampuan menjadi pembelajar mandiri (independent learner) sebagai prasyarat keberhasilan studi di UT bukanlah kemampuan yang terbangun dan terbentuk secara tiba-tiba. Akan tetapi, harus dibangun secara bertahap melalui intervensi yang dilakukan oleh UT sebagai penyelenggara layanan pendidikan tinggi. Ada pun untuk membangun kesiapan dan keberhasilan mereka belajar di UT dengan sistem (Pembelajaran Jarak Jauh (PJJ), diperlukan kegiatan pembekalan yang memadai yang disebut dengan Edukasi Kesiapan Belajar Mahasiswa (EKBM) khususnya mahasiswa baru dan Tutorial yang mendesain kemandirian mahasiswa dalam belajar. Kegiatan Edukasi Kesiapan Belajar Mahasiswa Baru dilakukan melalui Orientasi Studi Mahasiswa Baru (OSMB) dan Pelatihan Keterampilan Belajar Mandiri (KBM). Pendesainan kemandirian mahasiswa dalam belajar dapat dikemas melalui aspek skenario tutorial, aspek pendekatan dan strategi tutorial, aspek dalam bentuk pemberian tugas, dan teknik mengevaluasi tugas secara terpadu.

Hanya saja, konsep belajar mandiri tidak dapat disamakan dengan belajar sendiri. Sebab, hakikatnya belajar mandiri adalah tumbuhnya kemauan dan keterampilan mahasiswa dalam proses belajar tanpa bantuan orang lain. Dalam belajar mandiri dibutuhkan kesiapan kondisi kognitif, afektif dan psikomotor serta fasilitas tertentu. Untuk 
itu, Tutor sebagai fasilitator benar-benar dapat mengemas program belajar mandiri tersebut dengan baik.

Belajar mandiri memberikan kesempatan kepada mahasiswa untuk menentukan tujuan belajarnya, merencanakan proses belajarnya, menggunakan sumber-sumber belajar yang dipilihnya, membuat keputusan-keputusan akademis, dan melakukan kegiatankegiatan yang dipilihnya untuk mencapai tujuan belajarnya. (Brookfield, 1984: 50). Mahasiswa diberi peluang secara aktif berpartisipasi dalam menentukan apa yang akan dipelajari dan bagaimana cara belajarnya.

Ciri utama dalam belajar mandiri adalah pengembangan dan peningkatan ketrampilan dan kemampuan mahasiswa untuk melakukan proses belajar secara mandiri. Ciri yang lain dalam belajar mandiri adalah mahasiswa mempunyai tanggung jawab yang besar atas proses belajarnya. Hal ini relevan dengan matakuliah Teknik Penulisan Karya IImiah. Mengingat, salah satu kompetensi yang harus dimiliki oleh mahasiswa UT pada akhir studinya adalah kompetensi membuat karya tulis ilmiah yakni menulis artikel ilmiah.

Berdasarkan hasil studi pendahuluan terhadap karya ilmiah yang ditulis mahasiswa, masih banyak ditemukan karya tulis yang belum memenuhi standar sebagai karya ilmiah yang baik dan memadai. Temuan penelitian Julaeha (2009) menyebutkan bahwa salah satu faktor penghambat pelaksanaan pembimbingan adalah rendahnya kemampuan dan motivasi mahasiswa untuk membuat tulisan ilmiah.

Untuk itu, penelitian ini memiliki target pencapaian khusus sebagai berikut: (1) memperoleh gambaran tentang efektivitas pembentukan belajar mandiri melalui Pelatihan Kegiatan Belajar Mandiri dalam meningkatkan kemampuan Penulisan
Karya IImiah di S1 PGSD-UT Pokjar Pamekasan 2017-2018.2; (2) memperoleh gambaran tentang efektivitas pembentukan belajar mandiri melalui perancangan tutorial dalam meningkatkan kemampuan Penulisan Karya IImiah di S1 PGSD-UT Pokjar Pamekasan 2017-2018.2.

Berdasarkan tujuan tersebut, penelitian ini dilaksanakan menggunakan pendekatan penelitian deskriptif-kualitatif.

Proses analisis data dimulai dengan menelaah seluruh data, melakukan reduksi data, menyusunnya dalam satuan-satuan, dan menganalisnya dengan prosentase. Analisis data penelitian dilakukan dengan teknik analisis kuantitatif dan kualitatif. Data yang bersifat kuantitatif dianalisis dengan menggunakan penghitungan prosentase. Langkah ini merupakan langkah awal menuju keseluruhan proses analisis deskriptif kualitatif. Analisis data deskriptif kuantitatif berupa prosentase akan dijadikan dasar bagi penentuan efektivitas pada analisis deskriptif kualitatif dari variabel yang diteliti.

Aktivitas analisis meliputi: reduksi data, penyajian data, penyimpulan dan verifikasi. Kegiatan reduksi data meliputi klasifikasi data, pengkodean data sesuai dengan jenis data. Data disajikan dalam bentuk deskripsi.yang dilanjutkan dengan pemaknaan dan penyimpulan.

\section{Hasil Penelitian}

Berdasarkan hasil pengumpulan data, hasil penelitian dikelompokkan dalam tiga kategori, yakni sajian data angket kegiatan PKBM, sajian data RAT/SAT dan tampilannya, dan sajian data hasil tugas penulisan karya ilmiah. Hasil penilaian terhadap masing-masing data tersebut dikelompokkan dalam lima kategori, yakni: sangat buruk, buruk, cukup, baik, sangat baik. Ada pun sajian dari masing-masing data hasil penilaian tersebut sebagai berikut. 
Sulistiyono, Barokah Widuroyekti

\begin{tabular}{|c|c|c|c|c|c|}
\hline Komponen & Aspek yang Dinilai & $\begin{array}{l}\text { Skor } \\
(T=5)\end{array}$ & Jumah & $\begin{array}{l}\text { Rata-rata } \\
\text { Skorl } \\
\text { komponen }\end{array}$ & Prosentase \\
\hline \multicolumn{2}{|c|}{ Pelatihan Kebiasaan Belajar Mandiri } & & $\begin{array}{c}21 \\
\text { Mahasisw } \\
\text { a }\end{array}$ & & \\
\hline & $\begin{array}{c}\text { Relevansi kegiatan dengan } \\
\text { kebutuhan }\end{array}$ & 5 & 19 & \multirow{6}{*}{4} & $90 \%$ \\
\hline & Pelaksanaan Pelatihan KBM & 5 & 19 & & $90 \%$ \\
\hline & Materi Pelatihan KBM & 5 & 20 & & $95 \%$ \\
\hline & Kemampuan Instruktur & 4 & 19 & & $90 \%$ \\
\hline & Kesiapan panitia & 2 & 19 & & $90 \%$ \\
\hline & Fasilitas dan konsumsi & 3 & 19 & & $90 \%$ \\
\hline \multicolumn{2}{|c|}{$\begin{array}{l}\text { Tampilan Tutor dalam Pendesainan } \\
\text { Keterampilan Belajar Mandiri }\end{array}$} & & $\begin{array}{c}8 \\
\text { Peertemu } \\
\text { an }\end{array}$ & & \\
\hline & aspek skenario tutorial & 4 & 5 & \multirow{5}{*}{4} & $62 \%$ \\
\hline & Aspek pendekatan & 4 & 5 & & $62 \%$ \\
\hline & Aspek strategi tutorial & 4 & 6 & & $75 \%$ \\
\hline & $\begin{array}{l}\text { Aspek dalam bentuk } \\
\text { pemberian tugas }\end{array}$ & 4 & 7 & & $85 \%$ \\
\hline & $\begin{array}{l}\text { Aspek teknik mengevaluasi } \\
\text { tugas secara terpadu }\end{array}$ & 4 & 7 & & $85 \%$ \\
\hline \multicolumn{2}{|c|}{ Hasil Karya IImiah Konseptual Mahasiswa } & & $\begin{array}{c}21 \\
\text { Mahasisw } \\
\text { a }\end{array}$ & & \\
\hline & $\begin{array}{l}\text { Judul artike dan Nama } \\
\text { Penulis }\end{array}$ & 4 & 17 & \multirow{7}{*}{3} & $80 \%$ \\
\hline & Abstrak & 2 & 15 & & $70 \%$ \\
\hline & Pendahuluan & 3 & 15 & & $70 \%$ \\
\hline & Kajian Pustaka & 3 & 15 & & $70 \%$ \\
\hline & Pembahasan & 3 & 18 & & $86 \%$ \\
\hline & Simpulan dan Saran & 2 & 17 & & $80 \%$ \\
\hline & Daftar Pustaka & 4 & 19 & & $90 \%$ \\
\hline
\end{tabular}

\section{Hasil Penelitian Kegiatan PKBM}

Hasil kegiatan PKBM dengan subkomponen relevansi kegiatan dengan kebutuhan pencapaian pelaksanaan Pelatihan KBM pada tingkat kualitas yang sangat baik dengan menjawab skor 5 yang prosentasenya $90 \%$ dari jumlah 21 mahasiswa yakni 19 mahasiswa dan termasuk pada kategori sangat efektif. Sedangkan kegiatan PKBM dengan subkomponen tentang Materi Pelatihan KBM mencapai tingkat kualitas yang sangat baik dengan menjawab skor 5 yang prosentasenya $95 \%$ dari jumlah 21 mahasiswa yakni 20 mahasiswa dan termasuk pada kategori juga sangat efektif. Sementara, tiga subkomponen kegiatan Pelatihan KBM yakni: tentang kemampuan Instruktur mencapai tingkat kualitas baik dengan menjawab skor 4 yang prosentasenya $90 \%$ dari jumlah 21 mahasiswa yakni 19 mahasiswa dan termasuk pada kategori efektif; kesiapan panitia mencapai tingkat kualitas buruk dengan menjawab skor 2 yang prosentasenya $90 \%$ dari jumlah 21 mahasiswa yakni 19 mahasiswa dan termasuk kategori tidak efektif; serta fasilitas dan konsumsi juga mencapai tingkat kualitas cukup baik dengan menjawab skor 3 yang prosentasenya $90 \%$ dari jumlah 21 mahasiswa yakni 19 mahasiswa dan termasuk kategori efektif.

\section{Hasil Sajian Tampilan Tutor}

Data dari hasil observasi terhadap tampilan tutor dalam mengimplentasikan konsep penanaman pembiasaan belajar mandiri sesuai RAT dan SAT yang digunakannya adalah berikut ini. 
Implementasi aspek skenario tutorial sesuai RAT dan SAT teramati dengan pencapaian tingkat kualitas baik dengan perolehan skor 4 yang prosentasenya $62 \%$ dari jumlah 8 pertemuan tutorial yakni sebanyak 5 pertemuan dan termasuk pada kategori cukup efektif; Implementasi aspek pendekatan tutorial sesuai RAT dan SAT teramati dengan pencapaian tingkat kualitas baik dengan perolehan skor 4 yang prosentasenya $62 \%$ dari jumlah 8 pertemuan tutorial yakni sebanyak 5 pertemuan dan termasuk pada kategori cukup efektif; Implementasi aspek strategi tutorial sesuai RAT dan SAT teramati dengan pencapaian tingkat kualitas baik dengan perolehan skor 4 yang prosentasenya $75 \%$ dari jumlah 8 pertemuan tutorial yakni sebanyak 6 pertemuan dan termasuk pada kategori efektifl; Implementasi aspek dalam bentuk pemberian tugas tutorial sesuai RAT dan SAT teramati dengan pencapaian tingkat kualitas baik dengan perolehan skor 4 yang prosentasenya $85 \%$ dari jumlah 8 pertemuan tutorial yakni sebanyak 7 pertemuan dan termasuk pada kategori sangat efektifl; Implementasi aspek teknik mengevaluasi tugas tutorial secara terpadu sesuai RAT dan SAT teramati dengan pencapaian tingkat kualitas baik dengan perolehan skor 4 yang prosentasenya $85 \%$ dari jumlah 8 pertemuan tutorial yakni sebanyak 7 pertemuan dan termasuk pada kategori sangat efektifl.

\section{Hasil Penilaian Karya IImiah Konseptual Mahasiswa}

Hasil penilaian terhadap karya ilmiah konseptual mahasiswa yang merupakan capaian tujuan akhir dari keseluruhan implementasi kegiatan tutorial untuk matakuliah Teknik Penulisan Karya IImiah sebagai berikut. Hasil penilaian terhadap aspek judul artikel dan nama penulis dengan pencapaian tingkat kualitas baik dengan perolehan skor 4 yang prosentasenya $80 \%$ dari jumlah 21 mahasiswa yakni sebanyak 17 mahasiswa dan termasuk pada kategori efektif; Hasil penilaian terhadap aspek abstrak dengan pencapaian tingkat kualitas buruk dengan perolehan skor 2 yang prosentasenya $70 \%$ dari jumlah 21 mahasiswa yakni sebanyak 15 mahasiswa dan termasuk pada kategori cukuptidak efektif; Hasil penilaian terhadap aspek pendahuluan dengan pencapaian tingkat kualitas cukup baik dengan perolehan skor 3 yang prosentasenya $70 \%$ dari jumlah 21 mahasiswa yakni sebanyak 15 mahasiswa dan termasuk pada kategori cukup efektif; Hasil penilaian terhadap aspek kajian pustaka dengan pencapaian tingkat kualitas cukup baik dengan perolehan skor 3 yang prosentasenya $70 \%$ dari jumlah 21 mahasiswa yakni sebanyak 15 mahasiswa dan termasuk pada kategori cukup efektif; Hasil penilaian terhadap aspek pembahasan dengan pencapaian tingkat kualitas cukup baik dengan perolehan skor 3 yang prosentasenya $86 \%$ dari jumlah 21 mahasiswa yakni sebanyak 18 mahasiswa dan termasuk pada kategori cukup efektif; Hasil penilaian terhadap simpulan dan saran dengan pencapaian tingkat kualitas buruk dengan perolehan skor 2 yang prosentasenya $80 \%$ dari jumlah 21 mahasiswa yakni sebanyak 17 mahasiswa dan termasuk pada kategori tidak efektif; Hasil penilaian terhadap daftar pustaka dengan pencapaian tingkat kualitas baik dengan perolehan skor 4 yang prosentasenya $90 \%$ dari jumlah 21 mahasiswa yakni sebanyak 19 mahasiswa dan termasuk pada kategori sangat efektif.

\section{Pembahasan}

Kemampuan menjadi pembelajar mandiri (independent learner) sebagai prasyarat keberhasilan studi di UT hendaknya tetap dibangun secara bertahap 
Sulistiyono, Barokah Widuroyekti

melalui intervensi yang dilakukan oleh UT melalui pembekalan yang memadai yang disebut dengan Edukasi Kesiapan Belajar Mahasiswa (EKBM) khususnya mahasiswa baru dan melaui kegiatan tutorial yang terdesain kemandirian belajarnya. Kegiatan Edukasi Kesiapan Belajar Mahasiswa Baru dilakukan melalui Orientasi Studi Mahasiswa Baru (OSMB) dan Pelatihan Keterampilan Belajar Mandiri (KBM). Kemandirian dalam belajar dapat didesain melalui aspek skenario tutorial, aspek pendekatan dan strategi tutorial, aspek dalam bentuk pemberian tugas, dan teknik mengevaluasi tugas secara terpadu dalam setiap pertemuan tutorialnya.

RAT dan SAT yang dibuat dan yang dikembangkan oleh tutor telah memasukkan konsep-konsep yang dapat menanamkan kebiasaan belajar mandiri mahasiswa. Rancangan skenario tutorialnya mencerminkan dari pendekatan dan strategi yang digunakan. Rumusan kompetensi khususnya juga operasional dan bisa megukur tingkat keterlibatan mahasiswa dalam kegiatan tutorial yang dilaksanakan. Di samping itu, ketiga bentuk tugas yang dibuatnya mengarah pada target penguasaan konsep materi dan proses pembiasaan mahasiswa belajar mandiri dalam mengerjakan tugas. Untuk itu, pemberian skor baik menjadi hal yang wajar. Mengingat, konsep belajar mandiri telah terwadai dalam rancangan RAT dan SAT yang dibuatnya. Hanya saja, tidak semua pertemuan tutorialnya cakupan tersebut terwadai.

Tampilan tutor dari masing-masing pertemuan terekam sesuai dengan rancangan RAT dan SAT yang dibuatnya. Implementasi tersebut juga didukung dengan penguasaan materi dan juga bagaimana menciptakan suasana tutorial yang kndusif dan banyak melibatkan mahasiswa untuk mengambil inisiatif membahas persoalan modul yang terkait dengan masalah-masalah yang ada di sekolah untuk dijadikan topik kajian pembahasan materi penulisan karya ilmiah. Hal tersebut sesuai dengan petunjuk dan harapan dalam setiap tugas yang diberikan yang tujuan akhirnya mahasiswa memiliki wawasan untuk terbiasa dan terampil membuat karya ilmiah.

Untuk itu, tampilan tutor jika dilihat kesesuaiannya dengan RAT dan SAT yang dibuatnya dapat dikategorikan baik. Penulisam Karya Ilmiah Mahasiswa Tugas akhir tutorial Penulisan Karya IImiah, mahasiswa disuruh membuat karya ilmiah konseptual yang didasarkan pemahaman terhadap tugas-tugas sebelumnya dan pemahaman materi tentang teori penulisan karya ilmiah. Tugas tersebut diberikan untuk dikerjakan di rumah. Tugas tersebut tetap terkontrol dari keasliannya. Mengingat, topik yang ditulis masing-masing mahasiswa harus sesuai dengan tugas sebelumnya. Penyusunan karya ilmiahnya juga harus memenuhi karakteristik penulisan karya ilmiah yang benar.

Di samping itu, juga disampaikan pada penyampaian tugas bahwa penggunaan bahasa dan bahasan isi dari tulisan tersebut hendaknya mengikuti aturan tulisan karya ilmiah yang benar dan baik. Bahkan, tutor menyampaikan bahwa yang terpenting tulisan karya ilmiah yang dibuatnya hasil pikiran dan karya mahasiswa sendiri. Artinya, etika pengambilan pendapat dan rujukan hendaknya mengikuti aturan penulisan karya ilmiah.

RAT dan SAT yang dibuat dan yang dikembangkan oleh tutor telah memasukkan konsep-konsep yang dapat menanamkan kebiasaan belajar mandiri mahasiswa. Rancangan skenario tutorialnya mencerminkan dari pendekatan dan strategi yang digunakan. Rumusan kompetensi khususnya juga operasional dan bisa megukur tingkat keterlibatan mahasiswa dalam kegiatan tutorial yang 
dilaksanakan. Di samping itu, ketiga bentuk tugas yang dibuatnya mengarah pada target penguasaan konsep materi dan proses pembiasaan mahasiswa belajar mandiri dalam mengerjakan tugas. Untuk itu, pemberian skor baik menjadi hal yang wajar. Mengingat, konsep belajar mandiri telah terwadai dalam rancangan RAT dan SAT yang dibuatnya. Hanya saja, tidak semua pertemuan tutorialnya cakupan tersebut terwadai.

Tampilan tutor dari masing-masing pertemuan terekam sesuai dengan rancangan RAT dan SAT yang dibuatnya. Implementasi tersebut juga didukung dengan penguasaan materi dan juga bagaimana menciptakan suasana tutorial yang kndusif dan banyak melibatkan mahasiswa untuk mengambil inisiatif membahas persoalan modul yang terkait dengan masalah-masalah yang ada di sekolah untuk dijadikan topik kajian pembahasan materi penulisan karya ilmiah. Hal tersebut sesuai dengan petunjuk dan harapan dalam setiap tugas yang diberikan yang tujuan akhirnya mahasiswa memiliki wawasan untuk terbiasa dan terampil membuat karya ilmiah.

Untuk itu, tampilan tutor jika dilihat kesesuaiannya dengan RAT dan SAT yang dibuatnya dapat dikategorikan baik. Penulisam Karya IImiah Mahasiswa sebagai Tugas akhir tutorial Penulisan Karya IImiah, mahasiswa disuruh membuat karya ilmiah konseptual yang didasarkan pemahaman terhadap tugas-tugas sebelumnya dan pemahaman materi tentang teori penulisan karya ilmiah. Tugas tersebut diberikan untuk dikerjakan di rumah. Tugas tersebut tetap terkontrol dari keasliannya. Mengingat, topik yang ditulis masing-masing mahasiswa harus sesuai dengan tugas sebelumnya. Penyusunan karya ilmiahnya juga harus memenuhi karakteristik penulisan karya ilmiah yang benar.
Di samping itu, juga disampaikan pada penyampaian tugas bahwa penggunaan bahasa dan bahasan isi dari tulisan tersebut hendaknya mengikuti aturan tulisan karya ilmiah yang benar dan baik. Bahkan, tutor menyampaikan bahwa yang terpenting tulisan karya ilmiah yang dibuatnya hasil pikiran dan karya mahasiswa sendiri. Artinya, etika pengambilan pendapat dan rujukan hendaknya mengikuti aturan penulisan karya ilmiah.

Secara umum kualitas tulisan karya ilmiah konseptual mahasiswa jika dilihat dari komponen yang harus ada dalam tulisan karya ilmiah konseptual dapat dikategorikan baik. Begitu juga, prosentase sejumlah penguasaan dari peerta tutorial juga dalam kategori efektivitasnya baik. Artinya, implementasi tutorial dalam matakuliah Teknik Penulisan Karya IImiah yang didesain dengan menanamkan pembiasaan belajar mandiri memberikan kontribusi yang baik terhadap kemandirian mahasiswa dalam pembuatan karya ilmiah.

\section{Kesimpulan}

Berdasarkan hasil analisis dan pembahasan, diperoleh simpulan hasil penelitian sebagai berikut. Pertama, pembentukan belajar mandiri melalui Pelatihan Keterampilan Belajar Mandiri dalam meningkatkan kemampuan Penulisan Karya Ilmiah di S1 PGSD-UT Pokjar Pamekasan 2017-2018.2 mencapai kualitas skor baik dan perolehan penguasaan yang sangat efektif. Kedua, pembentukan belajar mandiri melalui perancangan tutorial dalam peningkatan kemampuan Penulisan Karya IImiah di S1 PGSD-UT Pokjar Pamekasan 2017 2018.2 mencapai skor baik dan perolehan penguasaan yang efektif. Ketiga, hasil karya ilmiah mahasiswa mencapai kualitas skor cukup dan perolehan penguasaan yang efektif. 
Sulistiyono, Barokah Widuroyekti

Dengan demikian simpulan hasil penelitian ini membawa implikasi terhadap upaya pembentukan belajar mandiri mahasiswa S1 PGSD-UT pada khususnya dan mahasiswa UT pada umumnya. Untuk itu, kegiatan Pelatihan Keterampilan Belajar Mandiri hendaknya tetap dilakukan melalui kegiatan Edukasi Kesiapan Belajar Mahasiswa Baru ketika Orientasi Studi Mahasiswa Baru (OSMB). Hanya saja, materi pelatihan yang terkait dengan cara sukses belajar di UT lebih diperdalam lagi.

Di samping itu, bagi para tutor dalam mendesain tutorialnya baik tuton mau pun tutorial tatap muka hendaknya memasukkan pembentukan belajar mandiri dalam pendekatan serta strategi dan skenario tutorialnya pada setiap pertemuannya.

\section{Daftar Pustaka}

Anggoro, M.T., dkk. 2008. Metode Penelitian, Jakarta: Universitas Terbuka

Arikunto, S. 2013. Manajemen Penelitian. Jakarta: Rineka Cipta.

Borg, W.R. \& Gall, M.D. (1983). Education Research : An Introduction. New York \& London: Longman.

Julaeha, S. 2009. Pembimbingan Refleksi Pembelajaran dalam PKP: Suatu Analisis Empiris pada Program S1 PGSD UT. Jurnal Pendidikan Volume 10 Nomor 2, September 2009. Diunduh tanggal 26 Oktober 2014.

Hadi, S. (1990). Statistik Pendidikan. Yogyakarta:Andi Offset.

Hadi, S. (1990). Metodologi Research. Yogyakarta:Andi Offset.

Milles \& Huberman, A. M. (1992). Analisis Data Qualitatif. Terjemah Tjetjep Rohendi Tohidi. Jakarta: Universitas Indonesia.

Wardani, I. G. A. K. 2007. Teknik Menulis Karya Ilmiah. Jakarta: Universitas Terbuka. 